\title{
Reagan's election cheering for science?
}

Harder line promises more spin-off funds

\section{Washington}

A big step for US politics, but a relatively small step for US science seems to be the main verdict on last week's presidential and congressional elections, with scientists unlikely to suffer as much from a swing to the right as other recipients of government spending.

President-elect Ronald Reagan has already said that he wants a 2 per cent across-the-board cut in the budgets of all federal agencies next year. But he is on record as supporting increased funds for research and development, a larger defence budget (with its spill-over into basic research) and the retention of both the Office of Science and Technology Policy (OSTP) and the post of President's Science Advisor.

The Republican takeover in the Senate has been as significant as Reagan's victory. The defeat of a significant handful of liberal Democrats will mean a major shift in the content of legislation. Again, however, the science budget may escape serious cuts, partly because key committee positions are likely to be filled by liberal Republicans, such as Senator Charles Mathias of Maryland, who have long been supporters of increased research funding.

Although little was said about science during the presidential election campaign, Mr Reagan has made it known in the past few weeks that he favours increased spending on science, particularly in areas related to defence needs. His main publicly-stated reservations were about the organization of OSTP, whose new staff would, he said, gather information in an informal way "rather than relying on 'blue ribbon panels' which are often partisan and work in secret".

The key question is who will fill the major science and technology positions in the new Reagan administration. Many of these choices are unlikely to be made until the new year. But preliminary discussions were held last weekend by a task force whose members indicate the likely directions of a Reagan science policy.

The task force was brought together by Dr Simon Ramo, co-founder of the advanced engineering firm TRW Inc., an adviser to Mr Reagan during the election campaign and former chairman of a congressionally-established federal science and technology committee under President Ford.

Co-chairman of the task force is Dr Arthur Bueche, vice-president of research and development for the General Electric

Company, a strong supporter of nuclear power and a possible Science Advisor.

Other members of the task force include Dr Harold Agnew, past director of the Los Alamos Scientific Laboratory; Dr Ed David, president of Exxon Research and, for a time, President Nixon's Science Advisor; Dr Frederick Seitz; Dr Guy Stever, ex-director of the National Science Foundation (NSF) and President Ford's Science Advisor: Dr Bill Baker past preTeller, : was go

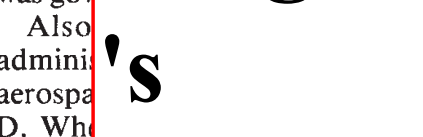

senior ice and r Albert D. Wh

\section{Pluelection}

\section{Plus}

Fast breeder research. One of $\mathrm{Mr}$ Reagan's first actions as President is likely to be to lift the embargo on the construction of the Liquid Metal Fast Breeder Reactor at Clinch River in Tennessee. Most of the major components have been built, but the test reactor's completion was held up by President Carter because of proliferation dangers and also a belief that fast breeder reactors are unlikely to be needed in the United States until well into the next century. Utility companies, however, which have provided a substantial amount of the funds, are keen to see the project completed, and are now likely to get their way.

Chemical weapons. President-elect $\mathrm{Mr}$ Reagan is also likely to give the go-ahead to a new facility for producing binary chemical weapons, favoured in Congress but, following President Nixon's earlier ban on their production, requiring a presidential declaration that such weapons are needed. In a campaign statement, Mr Reagan said that since binary weapons are much safer to stockpile and transport than existing stockpiles of poison gas, "we should proceed with preparation to convert to binary weapons".

Science court. In another statement, Reagan also said that he would explore the feasibility of a "science court" to help arrange public discussions of controversial scientific issues, a proposal that generated considerable publicity four years ago, but has since lapsed into relative obscurity.

House of Representatives. The House has lost one of its three scientist members, Mr Mike McCormack (see below), but has gained another, Mr Jim Coyne, an energy analyst and president of the Coyne Chemical Corporation. With Mr Coyne's election, all three scientists in the House are now Republican.
Aircraft Corporation and a strong supporter of the commercialization through private industry of communications and Earth monitoring satellites.

One immediate task for the committee is to select a new administrator for the National Aeronautics and Space Administration (NASA) to succeed Dr Robert Frosch, who has already announced his intention to take up the position of president of the new National Association of Engineering Societies in January.

Less certain is whether an immediate successor will be sought for Donald Dr Fredrickson, director of the National Institutes of Health. Dr Fredrickson was
Mr Mike McCormack, previously chairman of the House Science and Technology Committee's powerful energy research subcommittee, a strong advocate of nuclear power and a leading architect of recent nuclear fusion research legislation. Mr McCormack lost a tight race in Washington, where his district included the Department of Energy's Hanford Reservation.

Mr Jerome A. Ambro. A Democrat from Long Island, $\mathrm{Mr}$ Ambro was chairman of the Science and Technology Committee's subcommittee on natural resources and environment. He played a significant role in generating congressional approval for the $400-\mathrm{GeV}$ particle accelerator, ISABELLE, at the Brookhaven National Laboratory.

Environmental regulation. The loss of liberals such as Senators Frank Church (Idaho), John Culver (Iowa) and Gaylord Nelson (Wisconsin) and Representatives Bob Eckardt (Texas) and Andrew Maguire (New Jersey) will be a major blow to supporters of tough environmental regulation. Their only consolation is the re-election of another liberal, Congressman Morris Udall, chairman of the House Interior Committee. Mr Reagan has promised to repeal environmental and health legislation that is considered unnecessarily burdensome to industry.

Alfred Carnesale. The change in administration makes it unlikely that, as proposed by $\mathrm{Mr}$ Carter, Dr Alfred Carnesale, professor of public policy at Harvard's Kennedy School of Management, will now become chairman of the Nuclear Regulatory Commission. Although respected as a negotiator, Dr Carnesale is closely identified with a Ford-Mitre study that strongly influenced President Carter's stand against fast breeders.

David Dickson 
initially appointed by President Ford and was retained by President Carter; he had previously indicated that, even if Carter won, he would probably leave some time next year.

At NSF, although the Senate has approved the nomination of Dr John Slaughter as the new director, he has yet to be sworn in by the President and it is possible that $\mathrm{Mr}$ Reagan will wish to propose another candidate for what is supposed to be a relatively non-partisan appointment.

In the Senate, much will depend on how the chairmanships of the various committtees are allocated. One of the most prominent election casualties was Senator Warren Magnussen, long-time representative of the state of Washington, who as chairman of both the Senate Appropriations Committee and its health subcommittee had presided over a period of substantially increased funds for biomedical research.

If the Democrats had retained control, the subcommittee chairmanship could have passed to Mr William Proxmire, the scrourge of NSF. As ranking Republican, however, the position could now be taken by Senator Mathias - unless he prefers to take over Mr Proxmire's committee, which is responsible for the budgets of both NSF and NASA.

NASA's hopes for a relatively sympathetic hearing in the Senate have also been raised by the likelihood that the chairmanship of the Commerce Committee's science, technology and space committee will pass to Republican Senator and former astronaut Jack Schmitt, a keen supporter of the space programme and of increased funds for space science.

In the House of Representatives, which remains in the hands of the Democrats, the main changes will result from a possible reorganization of the Science and Technology Committee, where three subcommittee chairmen - Mr Mike McCormack, Mr Jerome Ambro and $\mathrm{Mr}$ John Lloyd - all lost their seats.

David Dickson

\section{Polish unions}

\section{Science not lost}

\section{Gdańsk}

In spite of the legal wrangles over registration and the need to prepare contingency plans for a possible nationwide protest strike, Poland's new independent self-governing trade union, Solidarność, has already started work. Among other things, it established, at the end of last month, its All-Poland Coordinating Commission for Science.

This at first glance is somewhat surprising, because the present policy of Solidarność, as the very name implies, is to build a strong union organization without subdivisions by trade or profession. Profession-based branches were originally planned for a later stage. Such a policy meets with the aspirations of the many briefly established new unions which, after the creation of Solidarność in midSeptember, were quick to amalgamate with it. As Dr Zdzislaw Bibrowski, erstwhile chairman of the Independent Trade Union of Scientific, Technical and Educational Workers (founded 8 September - see Nature 18 September - merged with Solidarność 13 October) explained, the members felt that in the present fluid situation they needed greater bargaining power and protection than a single small union could afford.

The Solidarność commission for science is not intended to be a separate interest group but rather a working party to elaborate the union's practical suggestions on the strengthening and renewal of the role of science in Poland.

Such a renewal is widely accepted as a major factor in getting the Polish economy out of its present crisis. It was the theme of last month's extraordinary General Assembly of the Polish Academy of Sciences and of a number of statements by academic and scientific bodies throughout the country. Lech Walesa, the leader of
Solidarność, told me last week "Speeches and declarations are not the point. We need concrete activity."

Such activity will be the role of the Solidarność commission. As Dr Wojciech Gruszecki, a chemistry lecturer at the Gdańsk Technical University and the Solidarność spokesman on science and technology explained, the commission, which has already met several times in Poland's leading academic centres (Krakow, Warsaw, Gdańsk, Wroclaw) hopes to work out some concrete proposals and submit them to the government; so too during the next few months will the Academy of Sciences and the country's various learned bodies. New legislation on science in Poland is now being drafted and will shortly be presented to the Sejm (parliament). In the current atmosphere of greater "openness" a lively public debate is expected.

On many points, including the need for greater autonomy in academic life and the lifting of censorship restrictions, the scientific and academic community is unanimous. Solidarność, however, would go further. As Dr Gruszecki explained, the union urges that science be treated as a non-

\section{University of Warsaw changes course}

\section{Warsaw}

The expected liberalization of Polish academic life is not entirely a consequence of the Gdańsk accords, according to a spokesman for the Polish Ministry of Higher Education and Science. Rather, he said, it is the cumulation of a continuing process. Thus the promise of a greater degree of selfgovernment for the universities was already foreseen in guidelines drawn up several months ago.

The ministry, it appears, wishes to seem well abreast of developments. This has been expecially the case since the surprise resignation at the end of September of the rector of Warsaw University. With widespread talk of academic autonomy, the ministry found it prudent to offer a compromise solution for the appointment of his successor. It proposed a list of three candidates, from whom the university senate made its final selection.

The senate is now committed to the principle of academic autonomy. The pro-rector, Dr Kazimierz Dobrowolski, stresses that the university should be able to draw up its own syllabuses and courses. Even under the present system, he says, some latitude is possible. In his own subject, biology, the university has been able to initiate courses in such new fields as environmental biology and molecular genetics. The result, he says, is that no student can graduate with simply a nineteenth century knowledge of biology.

The academic staff at the university is nevertheless concerned with falling standards among candidates for entry. The educational reform, introduced three years ago, which replaced the traditional eight years of primary schooling and four years lyceum by a comprehensive ten-year schooling, alarmed both parents and university staff. Although three years is strictly too short a time in which to assess the new system, the Ministry of Education has been quick to read the signs. Although no official announcement has yet been made, a recent article in the weekly Perspektywy suggests that the new Minister of Education, Krzysztof Kruszewski, intends to revert to the former system, with certain changes in syllabus incorporated from the ill-fated ten-year system.

A recent development at Warsaw University has been the inauguration of a course of Friday evening lectures by members of the Society for Academic Courses (the "Flying University") whose aim is to fill the gaps left by the state system of instruction. The lectures, held in the Adam Mickiewicz Hall (the largest lecture room in the university) are not, however, formally sponsored by the Society for Academic Courses. The hall is leased to the new Independent Students' Union, which invited the speakers. But, as one of the student organizers said, the correspondence between the list of lecturers in the Mickiewicz Hall and the members of the Society for Academic Courses is hardly coincidental.

Vera Rich 